\title{
Pengaruh jumlah ruas stek dan sumber pupuk nitrogen yang berbeda terhadap pertumbuhan dan produksi simplisia tanaman kumis kucing (Orthosiphon aristatus)
}

\section{(The effect of internode number of cutting and nitrogen fertilizer sources on growth and simplicia production of Java tea (Orthosiphon aristatus))}

\author{
A. D. Jayanti, Karno, dan B. A. Kristanto \\ Agroecotechnology, Faculty of Animal and Agricultural Sciences, Diponegoro University \\ Tembalang Campus, Semarang 50275 - Indonesia \\ Corresponding E-mail: astriedian@gmail.com
}

\begin{abstract}
The purpose of this research was to assess the effect of internode number of cutting and different sources of nitrogen fertilizer on the growth and production simplicia of Java tea (Orthosiphon aristatus). The experiment used completely randomized factorial design. The first factor was internode number of cutting $(3,5$, and 7 internodes) and the second factor was the source of nitrogen fertilizer (urea, chicken manure, cow manure, and goat manure). Growth parameters observed included total shoot length, leaf number, and root volume. The production parameters observed were the weight of fresh and dry leaves (simplicia). The data were analyzed by variance analysis and continued analyzed by Duncan's Multiple Range Test. The results showed that the internode number increased the total shoot length, leaf number, and root volume. Different sources of nitrogen fertilizer only increases root volume parameters. Both treatments did not increase the simplicia production of Java tea plants, and did not show any interaction on all parameters of the experiment.
\end{abstract}

Keywords : Cuttings, Orthosiphon aristatus, Simplicia, Source of Nitrogen

\begin{abstract}
ABSTRAK
Penelitian bertujuan untuk mengkaji pengaruh jumlah ruas stek dan sumber pupuk nitrogen yang berbeda pada pertumbuhan dan produksi simplisia tanaman Kumis Kucing (Orthosiphon aristatus). Rancangan percobaan yang digunakan adalah rancangan acak lengkap pola faktorial. Faktor pertama adalah jumlah ruas batang stek $(3,5$, dan 7 ruas) dan faktor kedua adalah sumber pupuk nitrogen (urea, pupuk kandang ayam, pupuk kandang sapi, dan pupuk kandang kambing). Parameter pertumbuhan yang diamati meliputi panjang tunas total, jumlah daun, dan volume akar. Parameter produksi yang diamati yaitu berat daun (simplisia) segar dan kering. Data dianalisis dengan analisis ragam dan dilanjutkan dengan uji berganda Duncan (Duncan's Multiple Range Test). Hasil penelitian menunjukkan peningkatan jumlah ruas stek mampu meningkatkan panjang tunas total, jumlah daun, dan volume akar. Penggunaan sumber hara nitrogen yang berbeda hanya meningkatkan parameter volume akar. Kedua perlakuan belum mampu meningkatkan produksi simplisia tanaman kumis kucing, serta tidak menunjukkan adanya interaksi pada seluruh parameter penelitian.
\end{abstract}

Kata kunci : Orthosiphon aristatus, Simplisia, Stek, Sumber Nitrogen.

\section{PENDAHULUAN}

Penggunaan obat bahan alam di masyarakat untuk mengatasi berbagai masalah kesehatan cenderung mengalami peningkatan. Obat bahan alam dapat membantu menjaga metabolisme tubuh dan memiliki efek samping yang relatif jauh lebih rendah dibandingkan dengan obat-obat kimia. Kumis kucing (Orthosiphon aristatus) merupakan salah satu tanaman obat yang banyak digunakan 
sebagai bahan baku dalam industri obat tradisional (Drianti, 2011). Kumis kucing ditetapkan menjadi tanaman utama pada program Saintifikasi Jamu oleh Kementerian Kesehatan, karena tanaman ini mampu memperbaiki fungsi ginjal. Kandungan bahan aktif utama yang paling stabil dan dijadikan zat identitas simplisia kumis kucing adalah senyawa sinensetin yang bersifat antibakteri (Pribadi et al., 2014).

Simplisia merupakan bahan alamiah berupa tanaman utuh, bagian tanaman, atau eksudat (zat kimia murni yang dipisahkan dari isi sel tanaman) tanaman yang digunakan sebagai obat dan belum mengalami pengolahan atau mengalami pengolahan secara sederhana (Sherley et al., 2010). Penggunaan simplisia kumis kucing pada industri besar dan menengah selain industri jamu pada tahun 2005 cukup tinggi yaitu sebesar 20 ton. Hal tersebut menunjukkan tanaman kumis kucing memiliki potensi yang besar dalam industri jamu atau pun selain jamu. Tingginya permintaan tersebut terkendala oleh produksi, kualitas, dan kontinyuitasnya yang masih mengalami fluktuasi. Upaya untuk meningkatkannya yaitu dengan teknik budidaya yang tepat, antara lain teknik perbanyakan dan pemupukan.

Tanaman kumis kucing umumnya diperbanyak melalui stek batang. Faktor yang mempengaruhi teknik perbanyakan tersebut salah satunya adalah jumlah ruas stek. Jumlah ruas yang semakin banyak akan meningkatkan jumlah tunas dan cabang. Jumlah tunas dan cabang yang semakin banyak akan memiliki potensi untuk menghasilkan daun yang lebih banyak (Delyani et $a l .$, 2017). Jumlah ruas juga berpengaruh terhadap bahan cadangan pada bahan tanam stek. Kandungan cadangan makanan yang semakin banyak dapat meningkatkan pertumbuhan stek tanaman. Berdasarkan penelitian sebelumnya dapat diketahui bahwa stek dengan jumlah lima ruas yang ditanam langsung menghasilkan pertumbuhan dan produksi simplisia terbaik (Rahmania dan Kurniawati, 2014). Pertumbuhan stek tanaman hingga panen pada fase vegetatif tanaman dipengaruhi oleh ketersediaan unsur hara terutama unsur nitrogen. Salah satu peran nitrogen dalam pertumbuhan tanaman adalah untuk merangsang pertunasan dan kemudian membentuk daun. Berdasarkan penelitian sebelumnya dapat diketahui bahwa pemupukan menggunakan kotoran ayam memberikan hasil terbaik pada parameter tinggi tanaman, berat basah dan kering tanaman kumis kucing (Affendy et al., 2011). Jenis sumber unsur hara nitrogen yang digunakan untuk budidaya tanaman kumis kucing dapat berpengaruh dalam ketersediaan unsur hara nitrogen selama fase pertumbuhan hingga panen. Penentuan jumlah ruas stek sebagai bahan tanam dan jenis sumber hara nitrogen sangat diperlukan agar teknik budidaya tanaman kumis kucing untuk produksi simplisia dapat lebih optimal.

Penelitian ini bertujuan untuk mengkaji pengaruh jumlah ruas stek, sumber pupuk nitrogen, serta interaksi antara keduanya terhadap pertumbuhan dan produksi simplisia tanaman kumis kucing.

\section{MATERI DAN METODE}

Penelitian lapang dilaksanakan pada bulan Juni sampai Oktober 2018 di Screen House, Desa Rendeng, Kecamatan Kota Kudus, Kabupaten Kudus. Analisis materi dan hasil penelitian di lakukan di Laboratorium Fisiologi dan Pemuliaan Tanaman serta Laboratorium Ekologi dan Produksi Tanaman, Departemen Pertanian, Fakultas Peternakan dan Pertanian, Universitas Diponegoro, Semarang.

\section{Materi Penelitian}

Bahan yang digunakan dalam penelitian ini meliputi tanaman induk yang kumis kucing berbunga putih (Orthosiphon aristatus), sumber nitrogen (urea, pupuk kandang ayam, pupuk kandang sapi, dan pupuk kandang kambing), tanah, arang sekam, tray, polybag $30 \times 30 \mathrm{~cm}$, dan label. Alat yang digunakan yaitu gunting tanaman, pisau okulasi, gembor, pita ukur, timbangan analitik, dan gelas/tabung ukur.

\section{Metode Penelitian}

Penelitian ini dilaksanakan menggunakan Rancangan Acak Lengkap (RAL) pola faktorial $3 \times 4$ dengan 3 kali ulangan. Faktor pertama adalah faktor jumlah ruas batang stek dengan 3 taraf perlakuan, yaitu B1: 3 ruas, B2: 5 ruas, dan B3: 7 ruas. Faktor kedua adalah jenis sumber unsur hara nitrogen dengan 4 jenis perlakuan, yaitu P0: urea, P1: pupuk kandang ayam, P2: pupuk kandang sapi, dan P3: pupuk kandang kambing. 
Kombinasi perlakuan sebanyak 12 dengan 3 kali ulangan, sehingga terdapat 36 unit percobaan yang setiap unit percobaan terdiri dari 1 stek tanaman kumis kucing. Data yang diperoleh kemudian dianalisis dengan analisis ragam untuk mengetahui pengaruh perlakuan dan dilanjutkan dengan uji berganda Duncan (Duncan's Multiple Range Test) pada taraf 5\%.

\section{Prosedur Penelitian}

Penelitian dilakukan dalam beberapa tahap yaitu tahap persiapan penelitian, perlakuan, pengambilan dan pengolahan data. Tahap persiapan penelitian berupa pembelian bahan dan peralatan yang dilakukan di toko pertanian daerah Semarang dan persiapan bahan tanam yaitu bibit kumis kucing, serta analisis unsur hara $\mathrm{N}$ dalam pupuk. Tahap perlakuan dilakukan dengan memperbanyak bibit tanaman kumis kucing (Orthosiphon aristatus) melalui stek dengan cara memotong ruas batang tanaman sesuai perlakuan (3, 5, dan 7 ruas). Media semai berupa arang sekam disiapkan dalam tray semai. Ruas batang dipotong kemudian ditanam secara tegak pada media semai yang telah disiapkan. Dosis sumber unsur hara $\mathrm{N}$ yang diberikan sebanyak $92 \mathrm{kgN} / \mathrm{ha}$ dan disetarakan pada berbagai sumber yang digunakan. Media tanam berupa tanah dan sumber pupuk N (pupuk kandang ayam, sapi, dan kambing) disiapkan dalam polybag. Stek batang yang telah berumur dua minggu setelah semai, kemudian dipindah tanamkan pada media tanam dalam polybag sesuai dengan perlakuan. Sumber pupuk N (urea) diberikan pada dua minggu setelah tanam. Pemeliharaan stek tanaman kumis kucing meliputi penyiraman yang dilakukan setiap hari, penyemprotan pestisida nabati yang dilakukan setiap minggu, dan penyiangan gulma dilakukan secara bertahap. Pengamatan dilakukan hingga tanaman siap panen yaitu saat tanaman berumur enam minggu setelah tanam.

\section{Parameter Penelitian}

(1) Panjang tunas total, diukur dari pangkal tunas sampai titik tumbuh tanaman (tunas) setiap unit penelitian menggunakan jangka dan pita ukur. (2) Jumlah daun, dihitung setiap daun yang tumbuh pada setiap unit penelitian. (3) Volume akar, dihitung dengan cara memasukkan akar ke dalam gelas/tabung ukur yang berisi air. (4) Bobot basah daun (simplisia), dihitung dengan cara menimbang daun setiap unit penelitian dengan menggunakan timbangan analitik. (5) Bobot kering daun (simplisia), dihitung dengan cara menimbang daun hasil panen yang telah dikeringkan dalam oven dengan suhu $105^{\circ} \mathrm{C}$ selama 24 jam.

\section{HASIL DAN PEMBAHASAN}

\section{Panjang Tunas Total}

Hasil analisis ragam menunjukkan bahwa tidak terdapat interaksi antara perlakuan jumlah ruas stek dan sumber nitrogen terhadap panjang tunas total stek tanaman kumis kucing. Perlakuan jumlah ruas stek memberikan pengaruh nyata, sedangkan perlakuan sumber nitrogen tidak memberikan pengaruh nyata terhadap panjang tunas total stek tanaman kumis kucing (Tabel 1). Hasil uji jarak berganda Duncan menunjukkan

Tabel 1. Panjang Tunas pada Stek Tanaman Kumis Kucing (Orthosiphon aristatus)

\begin{tabular}{|c|c|c|c|c|c|}
\hline \multirow[b]{2}{*}{$\begin{array}{c}\text { Jumlah Ruas } \\
\text { Stek }\end{array}$} & \multicolumn{4}{|c|}{ Sumber Nitrogen } & \multirow{2}{*}{ Rata-Rata } \\
\hline & Urea & $\begin{array}{c}\text { Pupuk } \\
\text { Kandang } \\
\text { Ayam } \\
\end{array}$ & $\begin{array}{c}\text { Pupuk } \\
\text { Kandang } \\
\text { Sapi } \\
\end{array}$ & $\begin{array}{c}\text { Pupuk } \\
\text { Kandang } \\
\text { Kambing }\end{array}$ & \\
\hline & 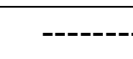 & --------- & naman ---- & ----------- & \\
\hline 3 ruas & 100,67 & 62,33 & 76,67 & 90,17 & $82,46^{\mathrm{b}}$ \\
\hline 5 ruas & 114,33 & 136,67 & 69,17 & 151,33 & $117,88^{\mathrm{a}}$ \\
\hline 7 ruas & 117,33 & 192,70 & 128,67 & 166,87 & $136,12^{\mathrm{a}}$ \\
\hline Rata-rata & 110,78 & 130,57 & 91,50 & 136,12 & \\
\hline
\end{tabular}


bahwa adanya perbedaan nyata pada perlakuan jumlah ruas stek terhadap panjang tunas total stek tanaman kumis kucing.

Hasil uji jarak berganda Duncan menunjukkan bahwa perlakuan jumlah ruas stek mampu meningkatkan panjang tunas total pada stek tanaman kumis kucing (Tabel 1). Jumlah ruas stek dapat mempengaruhi jumlah tunas yang tumbuh, semakin banyak jumlah ruas stek maka jumlah tunas yang tumbuh semakin banyak. Tunas yang tumbuh dapat mempengaruhi total panjang tunas stek tanaman kumis kucing. Menurut Santoso et al. (2008) ukuran bahan stek dapat
Moko (2006) menambahkan bahwa pemberian pupuk nitrogen mampu meningkatkan pertumbuhan tanaman, antara lain panjang tunas total pada stek.

\section{Jumlah Daun}

Hasil analisis ragam menunjukkan bahwa tidak terdapat interaksi antara perlakuan jumlah ruas stek dan sumber nitrogen terhadap jumlah daun pada stek tanaman kumis kucing. Perlakuan jumlah ruas stek memberikan pengaruh nyata, sedangkan perlakuan sumber nitrogen tidak memberikan pengaruh nyata terhadap jumlah daun

Tabel 2. Jumlah Daun pada Stek Tanaman Kumis Kucing (Orthosiphon aristatus)

\begin{tabular}{cccccc}
\hline \hline \multirow{2}{*}{$\begin{array}{c}\text { Jumlah } \\
\text { Ruas Stek }\end{array}$} & Urea & $\begin{array}{c}\text { Pupuk } \\
\text { Kandang } \\
\text { Ayam }\end{array}$ & $\begin{array}{c}\text { Pupuk } \\
\text { Kandang } \\
\text { Sapi }\end{array}$ & $\begin{array}{c}\text { Pupuk } \\
\text { Kandang } \\
\text { Kambing }\end{array}$ & Rata-Rata \\
\hline 3 ruas & 176,00 & 143,33 & 188,67 & 162,67 & $167,67^{\mathrm{b}}$ \\
5 ruas & 188,67 & 258,00 & 141,00 & 248,67 & $209,08^{\mathrm{b}}$ \\
7 ruas & 286,00 & 332,67 & 360,00 & 338,67 & $329,33^{\mathrm{a}}$ \\
\hline Rata-rata & 216,89 & 244,67 & 229,89 & 250,00 & \\
\hline Keterangan : & Superskrip yang berbeda pada kolom rata-rata menunjukkan perbedaan yang nyata $(\mathrm{p}<0,05)$
\end{tabular}

mempengaruhi keberadaan cadangan makanan yang akan menentukan pertumbuhan stek tanaman. Baskoro dan Purwoko (2010) menyatakan bahwa faktor yang mempengaruhi keberhasilan pertumbuhan stek antara lain adalah ketersediaan bahan makanan dan adanya tunas pada stek.

Hasil pemberian perlakuan sumber nitrogen menunjukkan bahwa tidak adanya pengaruh perlakuan dan tidak adanya interaksi antara kedua perlakuan terhadap panjang tunas total stek tanaman kumis kucing. Hal ini diduga karena kandungan nitrogen dari berbagai sumber nitrogen yang diberikan telah disetarakan dan masingmasing mampu memenuhi kebutuhan pertumbuhan tanaman kumis kucing. Menurut Samanhudi et al. (2010) kandungan nitrogen dalam berbagai sumber pupuk yang setara akan menyediakan unsur nitrogen untuk pertumbuhan tanaman dengan jumlah yang sama. Fiani dan pada stek tanaman kumis kucing (Tabel 2). Hasil uji jarak berganda Duncan menunjukkan bahwa adanya perbedaan nyata pada perlakuan jumlah ruas stek terhadap jumlah daun pada stek tanaman kumis kucing.

Hasil uji jarak berganda Duncan menunjukkan bahwa perlakuan jumlah ruas stek mampu meningkatkan panjang tunas pada stek tanaman kumis kucing (Tabel 2). Jumlah ruas stek yang semakin banyak akan memiliki potensi yang lebih besar untuk menghasilkan daun dari tunas yang tumbuh pada setiap ruas stek tanaman kumis kucing. Hal tersebut sesuai dengan pendapat Samanhudi et al. (2010) yang menyatakan bahwa jumlah buku dan cabang dapat mempengaruhi jumlah daun yang tumbuh pada stek tanaman kumis kucing. Pendapat tersebut diperkuat oleh Delyani et al. (2017) yang menyatakan bahwa jumlah ruas yang semakin banyak akan meningkatkan jumlah tunas dan cabang yang 
tumbuh pada stek, sehingga dapat meningkatkan jumlah daun yang dihasilkan.

Hasil pemberian perlakuan sumber nitrogen menunjukkan bahwa tidak adanya pengaruh perlakuan dan tidak adanya interaksi antara kedua perlakuan terhadap jumlah daun pada stek tanaman kumis kucing. Hal ini diduga karena nitrogen yang tersedia dari masing-masing sumber pupuk dapat mencukupi kebutuhan pertumbuhan tanaman kumis kucing. Menurut Fitrianah et al. (2012) kandungan nitrogen yang cukup dalam media tanam sangat berpengaruh dalam pertumbuhan tanaman, salah satunya adalah pembentukan organ tanaman berupa daun. Samanhudi et al. (2010) berpendapat bahwa jumlah nitrogen dalam tanah berpengaruh terhadap pertumbuhan tunas dan daun yang akan terbentuk.

\section{Volume Akar}

Hasil analisis ragam menunjukkan bahwa tidak terdapat interaksi antara perlakuan jumlah ruas stek dan sumber nitrogen terhadap volume akar stek tanaman kumis kucing. Perlakuan jumlah ruas stek dan sumber nitrogen masingmasing memberikan pengaruh nyata terhadap volume akar stek tanaman kumis kucing (Tabel 3). kumis kucing (Tabel 3). Jumlah ruas stek yang banyak memiliki kandungan cadangan makanan yang lebih banyak, sehingga dapat meningkatkan volume akar. Hal ini sesuai dengan pendapat Rosalia (2016) yang menyatakan bahwa stek yang memiliki kandungan cadangan lebih tinggi akan lebih mudah berakar, sedangkan stek yang memiliki kandungan cadangan lebih rendah cenderung mempercepat pertumbuhan tunas. Pendapat tersebut didukung oleh Santoso et al. (2008) yang menyatakan bahwa ukuran bahan stek dapat mempengaruhi kandungan karbohidrat pada batang. Semakin panjang ukuran bahan stek maka jumlah karbohidrat akan semakin banyak. Jumlah karbohidrat yang banyak pada stek dapat meningkatkan pertumbuhan akar.

Hasil uji jarak berganda Duncan menunjukkan bahwa perbedaan jenis sumber nitrogen dapat meningkatkan volume akar stek tanaman kumis kucing. Pupuk mengandung berbagai jenis unsur hara, salah satunya adalah nitrogen. Unsur hara nitrogen merupakan salah satu unsur yang berperan dalam pertumbuhan tanaman. Gigir et al. (2014) menyatakan bahwa tujuan dari pemupukan adalah menyediakan kebutuhan pertumbuhan dan perkembangan tanaman, salah satunya yaitu ketersediaan unsur

Tabel 3. Volume Akar Stek Tanaman Kumis Kucing (Orthosiphon aristatus)

\begin{tabular}{|c|c|c|c|c|c|}
\hline \multirow[b]{2}{*}{$\begin{array}{c}\text { Jumlah Ruas } \\
\text { Stek }\end{array}$} & \multicolumn{4}{|c|}{ Sumber Nitrogen } & \multirow[b]{2}{*}{ Rata-Rata } \\
\hline & Urea & $\begin{array}{c}\text { Pupuk } \\
\text { Kandang } \\
\text { Ayam } \\
\end{array}$ & $\begin{array}{c}\text { Pupuk } \\
\text { Kandang } \\
\text { Sapi } \\
\end{array}$ & $\begin{array}{c}\text { Pupuk } \\
\text { Kandang } \\
\text { Kambing }\end{array}$ & \\
\hline & & & 150 & ----- & \\
\hline 3 ruas & 8,33 & 10,00 & 15,00 & 18,33 & $12,92^{\mathrm{b}}$ \\
\hline 5 ruas & 10,00 & 21,67 & 11,67 & 25,00 & $17,08^{\mathrm{b}}$ \\
\hline 7 ruas & 13,33 & 23,33 & 28,33 & 36,67 & $25,42^{\mathrm{a}}$ \\
\hline Rata-rata & $10,56^{\mathrm{b}}$ & $18,33^{\mathrm{ab}}$ & $18,33^{\mathrm{ab}}$ & $26,67^{\mathrm{a}}$ & \\
\hline
\end{tabular}

Keterangan : Superskrip yang berbeda pada kolom rata-rata atau baris rata-rata menunjukkan perbedaan yang nyata $(p<0,05)$

Hasil uji jarak berganda Duncan menunjukkan bahwa adanya perbedaan nyata pada perlakuan jumlah ruas stek dan sumber nitrogen terhadap volume akar stek tanaman kumis kucing.

Hasil uji jarak berganda Duncan menunjukkan bahwa perlakuan jumlah ruas stek mampu meningkatkan volume akar stek tanaman hara nitrogen. Menurut Hajoeningtijas dan Budi (2008) ketersediaan unsur hara tanaman merupakan salah satu syarat tumbuh optimal tanaman yang dapat mempengaruhi pertumbuhan dan perkembangan sistem perkaran.

Hasil pemberian perlakuan menunjukkan tidak adanya interaksi antara pelakuan jumlah ruas 
stek dan sumber nitrogen terhadap volume akar stek tanaman kumis kucing. Hal ini diduga disebabkan karena perlakuan yang diberikan memberikan pengaruh masing-masing terhadap pertumbuhan stek tanaman kumis kucing. Menurut Baskoro dan Purwoko (2010) faktorfaktor yang mempengaruhi keberhasilan pertumbuhan stek antara lain adalah bahan stek dan ketersediaan bahan makanan. Rostiana et al. (2014) berpendapat bahwa pemberian pupuk akan menyediakan unsur hara yang dapat diserap tanaman secara langsung atau tidak langsung. Unsur hara yang diserap dapat memberikan pengaruh terhadap metabolisme tanaman dan peningkatan kandungan zat berkhasiat pada tanaman obat.

\section{Bobot Basah Daun}

Hasil analisis ragam menunjukkan bahwa tidak terdapat interaksi antara perlakuan jumlah ruas stek dan sumber nitrogen terhadap produksi segar daun tanaman kumis kucing. Perlakuan jumlah ruas stek dan sumber nitrogen masingmasing tidak memberikan pengaruh nyata terhadap produksi segar daun tanaman kumis kucing (Tabel 4). daun. Optimalisasi distribusi fotosintat berpengaruh pada massa daun tanaman. Stek dengan jumlah ruas yang lebih sedikit (ruas 3 dan 5) akan memiliki biomassa daun yang lebih besar karena fotosintat telah terkonsentrasi secara optimal untuk perkembangan daun. Stek ruas tujuh memiliki mata tunas yang lebih banyak dibandingkan dengan ruas lainnya, sehingga fotosintat lebih dimanfaatkan untuk pertumbuhan tunas-tunas baru dan menyebabkan perkembangan daun belum maksimal pada panen pertama. Hal tersebut menyebabkan produksi daun segar pada panen pertama masih belum menunjukkan perbedaan dan pengaruh nyata. Rahmania dan Kurniawati (2014) menyatakan bahwa semakin banyak jumlah buku pada stek maka jumlah mata tunas yang akan tumbuh menjadi tunas baru juga semakin banyak. Buntoro et al. (2014) menambahkan bahwa semakin banyak tunas baru yang akan tumbuh dapat menyebabkan fotosintat yang dihasilkan hanya akan teralokasikan untuk pertumbuhan tunas-tunas baru.

\section{Bobot Kering Daun}

Hasil analisis ragam menunjukkan bahwa tidak terdapat interaksi antara perlakuan jumlah

Tabel 4. Produksi Segar Daun Tanaman Kumis Kucing (Orthosiphon aristatus)

\begin{tabular}{|c|c|c|c|c|c|}
\hline \multirow[b]{2}{*}{$\begin{array}{c}\text { Jumlah Ruas } \\
\text { Stek }\end{array}$} & \multicolumn{4}{|c|}{ Sumber Nitrogen } & \multirow[t]{2}{*}{ Rata-Rata } \\
\hline & Urea & $\begin{array}{c}\text { Pupuk } \\
\text { Kandang } \\
\text { Ayam }\end{array}$ & $\begin{array}{c}\text { Pupuk } \\
\text { Kandang } \\
\text { Sapi }\end{array}$ & $\begin{array}{c}\text { Pupuk } \\
\text { Kandang } \\
\text { Kambing }\end{array}$ & \\
\hline & & & & & \\
\hline 3 ruas & 14,95 & 15,02 & 20,19 & 11,92 & 15,52 \\
\hline 5 ruas & 14,90 & 18,31 & 12,95 & 15,28 & 15,36 \\
\hline 7 ruas & 17,33 & 25,73 & 13,22 & 16,07 & 18,09 \\
\hline Rata-rata & 15,73 & 19,69 & 15,45 & 18,09 & \\
\hline
\end{tabular}

Berdasarkan Tabel 4 dapat dilihat bahwa perlakuan jumlah ruas stek, sumber nitrogen, dan interaksi antara keduanya tidak memberikan pengaruh nyata terhadap produksi segar daun tanaman kumis kucing. Hal ini diduga disebabkan karena pertumbuhan awal stek pada jumlah ruas yang lebih banyak akan lebih terkonsentrasi pada pertumbuhan tunas, sedangkan ruas yang lebih sedikit telah terkonsentrasi pada perkembangan ruas stek dan sumber nitrogen terhadap produksi simplisia tanaman kumis kucing. Perlakuan jumlah ruas stek dan sumber nitrogen masingmasing tidak memberikan pengaruh nyata terhadap produksi simplisia tanaman kumis kucing.

Berdasarkan Tabel 5 dapat dilihat bahwa perlakuan jumlah ruas stek, sumber nitrogen, dan interaksi antara keduanya tidak memberikan 
Tabel 5. Produksi Simplisia Stek Tanaman Kumis Kucing (Orthosiphon aristatus)

\begin{tabular}{cccccc}
\hline \hline & \multicolumn{4}{c}{ Sumber Nitrogen } & Rata-Rata \\
\cline { 2 - 6 } $\begin{array}{c}\text { Jumlah Ruas } \\
\text { Stek }\end{array}$ & Urea & $\begin{array}{c}\text { Pupuk } \\
\text { Kandang } \\
\text { Ayam }\end{array}$ & $\begin{array}{c}\text { Pupuk } \\
\text { Kandang } \\
\text { Sapi }\end{array}$ & $\begin{array}{c}\text { Pupuk } \\
\text { Kandang } \\
\text { Kambing }\end{array}$ & \\
\hline 3 ruas & 1,78 & 1,64 & 2,37 & 1,41 & 1,80 \\
5 ruas & 1,67 & 2,40 & 1,42 & 2,13 & 1,91 \\
7 ruas & 2,28 & 3,19 & 1,82 & 2,56 & 2,46 \\
\hline Rata-rata & 1,91 & 2,41 & 1,87 & 2,03 & \\
\hline
\end{tabular}

pengaruh nyata terhadap produksi simplisia tanaman kumis kucing. Hal ini diduga disebabkan karena akumulasi biomassa pada daun selama pertumbuhan awal stek tanaman belum optimal. Stek dengan ruas yang sedikit telah memiliki pertumbuhan tunas yang optimal dan terkonsentrasi pada perkembangan daun, sehingga daun memiliki biomassa yang telah maksimal pada panen pertama. Pertumbuhan tunas pada ruas stek yang lebih banyak belum maksimal, biomassa lebih dikonsentrasikan untuk pertumbuhan tunas sehingga perkembangan daun pada panen pertama belum optimal dan biomassa belum terakumulasi secara maksimal. Berdasarkan hasil pertumbuhan stek, ruas tujuh memiliki hasil yang lebih baik dibandingkan perlakuan lain terutama pada pertumbuhan dan perkembangan akar. Hal tersebut memungkinkan adanya peningkatan produksi simplisia pada periode panen berikutnya. Hajoeningtijas dan Budi (2008) berpendapat bahwa sistem perakaran yang baik pada tanaman dapat meningkatkan penyerapan hara dan air, sehingga biomassa yang akan dihasilkan dapat meningkat. Munurut Delyani et al. (2017) produksi simplisia kumis kucing cenderung akan meningkat dengan bertambahnya jumlah panen yang dilakukan.

\section{KESIMPULAN}

Berdasarkan penelitian yang telah dilaksanakan maka dapat disimpulkan bahwa peningkatan jumlah ruas stek mampu meningkatkan panjang tunas total, jumlah daun, dan volume akar stek tanaman kumis kucing. Penggunaan sumber hara nitrogen yang berbeda tidak berpengaruh pada pertumbuhan stek tanaman kumis kucing kecuali pada volume akar. Kedua perlakuan belum mampu meningkatkan produksi simplisia tanaman kumis kucing, serta tidak menunjukkan adanya interaksi pada seluruh parameter penelitian. Hasil pertumbuhan stek tanaman kumis kucing menunjukkan perlakuan jumlah ruas yaitu tujuh ruas lebih baik dibandingkan perlakuan lainnya terutama pada parameter akar, hal tersebut dapat memungkinkan adanya peningkatan produksi simplisia pada panen selanjutnya.

\section{DAFTAR PUSTAKA}

Affendy, H., M. Aminuddin, M. Azmy, M. A. Amizi, K. Assis, and A. T. Tamer. 2011. Effect of organic fertilizers application to the growth of Orthosiphon aristatus Benth. intercropped with Havea brasiliensis Willd. and Durio zibethinus Murr. Int. J. Agric. Research, 6 : 1 - 8 .

Baskoro, D. dan B. S. Purwoko. 2010. Pengaruh bahan perbanyakan tanaman dan jenis pupuk organik terhadap pertumbuhan tanaman Binahong (Anredera cordifolia (Ten.) Steenis). J. Hort. Indonesia, 2 (1) : 6 -13 .

Buntoro, B.H., R. Rogomulyo, dan S. Trisnowati. 2014. Pengaruh Takaran Pupuk Kandang dan Intensitas Cahaya Terhadap Pertumbuhan dan Hasil Temu Putih (Curcuma zedoaria L.). J. Vegetalika 3 (4) : $29-39$. 
Delyani, R., A. Kurniawati, M. Melati, dan D. N. Faridah. 2017. Produksi simplisia kumis kucing dengan perbedaan cara pemupukan dan ketinggian pangkas pada rotasi panen tiga minggu. J. Hortikultura Indonesia, 8 (3) : $209-217$

Drianti, A. 2011. Analisis permintaan tanaman obat pada industri obat tradisional di Kalimantan Selatan. J. Ekonomi Manajemen, 6 (1) : $31-41$.

Fiani, A. dan H. Moko. 2006. Pengaruh pupuk nitrogen terhadap produksi tunas dan kualitas stek pucuk Merawan. J. Penelitian Hutan Tanaman, 3 (1) : 45 - 52 .

Fitrianah, L., S. Fatimah, dan Y. Hidayati. Pengaruh komposisi media tanam terhadap pertumbuhan dan kandungan saponin pada dua varietas tanaman Gendola (Basella sp). J. Agrivor, 5 (1) : $34-46$.

Gigir, S. F., J. J. Rondonuwu, W. J. N. Kumolontang, dan R. L. Kawulusan. 2014. Respon pertumbuhan kemangi (Ocimum sanctum L) terhadap pemberian pupuk organik dan anorganik. J. Cocos, 5 (3) : 1 7.

Hajoeningtijas, O. D. dan G. P. Budi. 2008. Pengaruh jenis bahan pembenah tanah terhadap kuantitas dan kualitas tanaman kumis kucing (Orthosiphon aristatus (BI.) Miq.) dengan budidaya organik. J. Agritech, $10(1): 18-29$.

Pribadi, E. R., W. Lukman, dan B. S. Sembiring. 2014. Prospek perbaikan teknologi budidaya dan pascapanen kumis kucing di kabupaten Sukabumi. J. Littri, 20 (4) : 211 219.

Rahmania, R. dan A. Kurniawati. 2014. Penentuan ukuran stek kumis kucing (Orthosiphon aristatus Bl. Miq.) dan dosis pupuk kandang pada cara tanam langsung. J. Hort. Indonesia, 5 (3) : $189-202$.

Rosalia, F. 2016. "Pengaruh konsentrasi ZPT dan jumlah mata tunas terhadap pertumbuhan stek melati (Jasminum sambac)". Skripsi. Sekolah Tinggi Ilmu Pertanian Dharma Wacana Metro, Lampung.

Rostiana, O., R SMD., A. Ruhnayat, N. Bermawie, dan D. Iswantini. 2014. Respon Dua Aksesi Kumis Kucing (Orthosiphon aristatus (BLUME) MIQ.) terhadap Perlakuan Pemupukan di Daratan Tinggi. Prosiding Seminar Nasional Pertanian Organik. Bogor: 18 - 19 Juni 2014. Hal. $239-247$

Samanhudi, E. S. Muliawati, dan E. Setyorani. 2010. Kajian frekuensi pemberian air dan macam pupuk organik terhadap pertumbuhan dan hasil tanaman kumis kucing. J. Ilmiah Pertanian, 13 (8) : 70 - 85.

Santoso, B. B., Hasnam, Hariyadi, S. Susanto, dan B. S. Purwoko. 2008. Perbanyakan vegetatif tanaman jarak pagar (Jatropha curcas L.) dengan stek batang : pengaruh panjang dan diameter stek. Bulletin Agronomi, 36 (3) : $255-262$.

Sherley, B. Dwiyatmoko, A. Sianipar, Mardiaty, dan T. Usia. 2010. Acuan Sediaan Herbal. Badan Pengawas Obat dan Makanan Republik Indonesia, Jakarta. 